\title{
THE TRANSFER OF A COMPANY SEAT TO A DIFFERENT MEMBER STATE IN THE LIGHT OF THE RECENT „POLBUD“ DECISION
}

\author{
Hrvoje Markovinović * \\ Antun Bilić *
}

\begin{abstract}
This paper observes the transfer of a company seat to a different Member State as an expression of the EU freedom of establishment. The reason for such analysis is the recent and somewhat controversial "Polbud" decision. The Court decided that a company enjoys the freedom of establishment to transfer its registered seat to another Member State despite the fact that it will not perform any economic activity there. In addition, the Court held that the mandatory liquidation of a company goes beyond what is necessary to protect the legitimate interests of minority shareholders, creditors, and employees. The paper scrutinizes both findings. A special attention is devoted to the role of an actual economic activity for the notion of the freedom of establishment. The paper arrives to the conclusion that, along with the freedom to actually perform economic activity, the freedom of establishment includes the freedom to use all national legal forms suitable for performing of an economic activity. As to the second finding, although it is possible that the mandatory liquidation indeed goes beyond necessary, the Court failed to demonstrate that this was the case.
\end{abstract}

KEYWORDS: registered seat, real seat, transfer of a seat, freedom of establishment, economic activity, freedom of legal form

\footnotetext{
* Hrvoje Markovinović, PhD, associate professor at the Department for Commercial and Company Law, Faculty of Law, University of Zagreb; hrvoje.markovinovic@pravo.hr

** Antun Bilić, PhD, assistant professor at the Department for Commercial and Company Law, Faculty of Law, University of Zagreb; antun.bilic@pravo.hr
} 


\section{INTRODUCTION}

Functioning of the European Single Market presupposes, among other freedoms, the right of establishment in a territory of another Member State (Art. 49-55 TFEU $\left.{ }^{1}\right)^{2}$ Having in mind that the establishment can take a form of a company (Art. 49 (2) TFEU) and that companies themselves enjoy the right of establishment (Art. 54 TFEU), it could be expected that the companies are free to change their seat from one Member State to another at their will. However, as expressly stated in Art. 54 TFEU, companies are primarily formed in accordance with the law of a specific Member State, and, consequently, they exist only by virtue of its national legislation. ${ }^{3}$ This creates a tension between EU and national law - while EU law gives company a right to transfer its seat, both the Member State in which the company was initially incorporated (departure Member State) and the Member State in which the company wants to transfer its seat (destination Member State) set the requirements for the very existence of such company. Such tension cannot be solved by simply prioritizing either EU or national law. Instead, it is necessary to demarcate their competences as precisely as possible and to strike the right balance between conflicting interests.

This is further complicated by the fact that a seat of a company can be determined in multiple ways. Consequently, the seat can be a place where a company is registered, a place determined by company's articles of association, a place from which the company is managed or the place in which the company performs at least a part of its economic activity. Those places will, naturally, often coincide. This is especially true with the registered seat and the seat determined by company's articles of association, since the registration authority will carry out the registration on the basis of the articles of association. On the

1 Consolidated version of the Treaty on the Functioning of the European Union, OJ C 326, 26.10.2012, p. 47-390.

2 About the freedom of establishment in more detail see, e.g. Craig, P.; de Burca, G., EU Law, Text, Cases and Materials, Oxford University Press, 2015., p. 794; Goebel, R. J. et al., Cases and Materials on European Union Law, West Academic Publishing, 2015, p. 603; Barnard, C., The Substantive Law of the EU, The Four Freedoms, Oxford University Press, 2016, p. 381; Mathijsen, P. S. R. F., A Guide to European Union Law, Sweet \& Maxwell, 2010, p. 266; Steiner, J.; Woods, L., EU Law, Oxford University Press, 2009, p. 491; Korte S. in: Calliess, C.; Ruffert, M. (ed.), EUV/AEUV, C. H. Beck, München, 2018, Art. 49 AEUV; Forsthoff, U. in Grabitz, E.; Hilf, M.; Nettesheim, M. (ed.), Das Recht der Europäischen Union, C. H. Beck; München, 2018, AEUV Art. 49; Müller-Graf, P-C. in Streinz, R. (ed.), EUV/AEUV, C. H. Beck, München, 2018, AEUV Art. 49; Tiedje, J. in: von der Groeben, H.; Schwartze, J., Hatje, A. (ed.), Europäische Unionsrecht, Nomos, 2015, AEUV Art. 49.

3 Judgement of 27 September 1988, Daily Mail and General Trust PLC, C-81/87, ECLI:EU:C:1988:456, para. 19. 
other hand, in contemporary globalized economy, especially within the EU, it is common that the place of company's management or the place of company's economic activity (so-called "real seat") diverge from its registered seat. It is, moreover, common that a company conducts its economic activity in several countries or even that it is managed in a decentralized way.

The fact that Member States regulate the incorporation of their companies' means that they are free to determine the connection those companies must have with their national territory ${ }^{4}$ i.e. Member States are free to require the existence of a certain type of seat within their boundaries. In practice, they will at least require that the companies' registered seat is recorded by their registration authority or, otherwise, the system of the national company registration would become meaningless. Member States can also make registration of companies contingent upon a certain "real" connection with their territory, e.g. the location of company's management or performing of economic activity.

In addition to company law rules, Member States are generally free to designate private international law rules on how to determine the law applicable to companies (lex sociatatis). The connecting factor is usually either the place of company's registration, i.e. incorporation (incorporation theory), or the place of company's effective management (real seat theory). ${ }^{5}$

Consequently, the transfer of certain type of company seat depends on the role which that type of seat plays in the national company and private international law of the departure and the destination Member State. By registering itself in a Member State a company adopts a distinct legal form, specific for that legal system (e.g. LTD, SARL, GmbH). Therefore, a cross-border transfer of a registered seat almost always requires a conversion of transferring company in a legal form recognized in the destination Member State. Even if company forms from different Member States share the same name, due to the differences in national legislation they are rarely identical. ${ }^{6}$ If the destination Member State requires that its companies also have a "real seat" in its territory, the transferring company will be forced to transfer its management and/or economic activity. On the other hand, the sole transfer of a "real seat" will rarely lead to a change of legal personality, although the departure Member State might refuse to recognize such company as its own.

\footnotetext{
4 Müller-Graf, op. cit. in fn. 2., AEUV 54, para. 20.

5 Tiedje, op. cit. in fn. 2, AEUV 54, para. 35-40.

6 E.g. in both Germany and Austria private limited company is called Gesellschaft mit beschränkter Haftung, abbreviated $\mathrm{GmbH}$. However, for German $\mathrm{GmbH}$ minimum share capital is 25.000 EUR ( $\$ 5$ German GmbHG), and for Austrian GmbH 35.000 EUR ( 6 Austrian GmbHG).
} 
National rules on the seat and its transfer, however, are not allowed to restrict the freedom of establishment as defined by the EU law. The scope of the freedom to transfer the company seat is primarily defined by the case law of the Court of Justice of the European Union (the Court). Unlike with some other types of cross-border transformation, ${ }^{7}$ the existing EU secondary legislation does not regulate the cross-border transfer of the company seat or the cross-border conversion. Only recently, as a part of EU Company Mobility Package, European Commission issued a proposal for a directive that would comprehensively regulate cross-border conversions, mergers and divisions. ${ }^{8}$ European Commission also started an initiative to codify the private international company, possibly in the form of a new Rome Regulation. ${ }^{9}$

Since the case law of the Court has already been extensively scrutinized, this introduction will provide only a brief overview. In Daily Mail case, the Court found that the companies exist only by virtue of national legislation, and as long as a company wants to remain incorporated in the United Kingdom, the freedom of establishment does not authorize it to move its central management to Netherlands before it complies with the requirements set by UK law. ${ }^{10}$ Simply put, the departure Member State may prevent the sole transfer of a company's real seat.

In a series turn-of-the-century cases the Court held that the freedom of establishment precludes the destination Member State from restricting the transfer of a real seat, even if the transferring company does not exercise any economic activity in the departure Member State. To be more specific, in Centros case the Court found that Denmark cannot refuse to register a branch of a UK company even if the company was incorporated in UK only to avoid Danish requirements of a minimum share capital. ${ }^{11}$ The transferring company could not have abused the right of establishment since its objective is precisely to

\footnotetext{
7 Cross-border mergers which are regulated by the Directive (EU) 2017/1132 of the European Parliament and of the Council of 14 June 2017 relating to certain aspects of company law, OJ L 169, 30.6.2017, p. 46-127, Art. 118-134.

8 Proposal for a Directive of the European Parliament and of the Council amending Directive (EU) 2017/1132 as regards cross-border conversions, mergers and divisions, COM/2018/241 final - 2018/0114 (COD).

9 See Gerner-Beuerle, C.; Mucciarelli, F. M.; Schuster, E-P., Study on the Law Applicable to Companies, June 2016, p. 12. See also a proposal by the European Group for Private International Law (GEDIP), led by prof. Francisco Garcimartin, called The Law Applicable to Companies in the European Union, from October 2016.

10 Daily Mail, op. cit. in fn. 3, especially para. 19-24.

11 Judgement of 9 March 1999, Centros Ltd, C-212/97, ECLI:EU:C:1999:126.
} 
enable companies to pursue economic activities in Member States other than the country of their incorporation. ${ }^{12}$

Similarly, in Überseering case the Court found that Germany is not allowed to use the real seat theory to deny the legal capacity of a company incorporated in Netherlands which transferred its central management to Germany. ${ }^{13}$ In Inspire Art case the Court found that Netherlands could not impose the minimum share capital on a company incorporated in UK which wanted to conduct its economic activity exclusively in Netherlands..$^{14}$ Described cases are not contrary to the reasoning applied in Daily Mail. If a company derives its affiliation to a Member State from its registration, ${ }^{15}$ only that Member State can impose certain requirements, while the other Member States have to respect its freedom of establishment. ${ }^{16}$

All three cases recognize that the freedom of establishment could be restricted in order to prevent fraud or abuse or if there are some other overriding reasons of public interest,$^{17}$ such as the protection of minority shareholders, creditors, employees (workers) or tax law objectives ${ }^{18}$. However, measures that restrict freedom of establishment have to be appropriate for attaining their objective and should not go beyond necessary. ${ }^{19}$ The Court was generally very reluctant to recognize the fraud or abuse of the freedom of establishment, since its objective is exactly to enable companies to choose the most favorable combination of the registered and real seat. ${ }^{20}$ The Court was also reluctant to recognize that a measure does not go beyond what is necessary to achieve a legitimate objective. ${ }^{21}$ Nevertheless, in Cadbury Schweppes case the Court held that a Member State is allowed to restrict the freedom of establishment of wholly

\footnotetext{
12 Centros op. cit. in fn. 11, para. 23-27.

13 Judgement of 5 November 2002, Überseering BV v Nordic Construction Company Baumanagement GmbH (NCC), C-208/00, ECLI:EU:C:2002:632.

14 Judgement of 30 September 2003, Kamer van Koophandel en Fabrieken voor Amsterdam v Inspire Art Ltd, Case C-167/01, ECLI:EU:C:2003:512.

15 To be precise, Daily Mail does not equate the country of incorporation with the country of registration (Daily Mail, op. cit. in fn. 3, especially para. 23). However, at least as to the companies which need to be registered, the incorporation will be synonymous with registration.

16 Inspire Art, op. cit. in fn. 14, para. 103.

17 Centros op. cit. in fn. 11, para. 25, 34; Überseering, op. cit. in fn. 13, para. 92; Inspire Art, op. cit. in fn. 14, para. 105, 133.

18 Überseering, op. cit. in fn. 13, para. 92; Judgement of 13 December 2005, SEVIC Systems AG, C-411/03, ECLI:EU:C:2005:762, para. 28.

19 Centros, op. cit. in fn. 11, para. 34; Inspire Art, op. cit. in fn. 14, para. 133.

20 Centros, op. cit. in fn. 11, para. 27; Inspire Art, op. cit. in fn. 14, para. 96, 138, 139.

${ }^{21}$ Centros, op. cit. in fn. 11, para. 36-38, Inspire Art, op. cit. in fn. 14, para. 135.
} 
artificial arrangements which do not conduct any genuine economic activity, if their aim is to circumvent the application of Member State's legislation (in particular case - tax law). ${ }^{22}$

In none of the described cases, the Court decided on the transfer of a registered seat. This began to change with the SEVIC case, in which the Court held that the freedom of establishment precludes the destination Member State from restricting a transfer of the registered seat via merger. In particular, Germany was not allowed to refuse the registration of a merger in which a German company absorbed a Luxembourg company. ${ }^{23}$

In Cartesio, the Court decided on a case whose facts were similar to those of Daily Mail. ${ }^{24}$ The Court found that the freedom of establishment did not compel Hungary to permit Hungarian company to transfer its real seat to Italy and to register such transfer in Hungarian company register. As long as a company wants to retain its status of a company governed by Hungarian law, Hungary is authorized to require the existence of the seat within its territory. ${ }^{25}$ More interesting was an obiter dictum, according to which it would be different if a company completely detached itself from the departure Member State by converting itself into a company form of the destination Member State. In that case, the departure Member State would not be allowed to prevent such conversion by requiring winding up or liquidation of the company. ${ }^{26}$

That obiter dictum was soon tested in a Vale case, where an Italian company wanted to transfer both its registered and real seat to Hungary, converting itself into a company form of Hungarian law. ${ }^{27}$ Hungarian courts refused to register such transfer, explaining that Hungarian law allows only domestic conversions, between company forms of Hungarian national law. The Court found that this constituted a restriction of the freedom of establishment. As long as the transfer is accompanied by an actual pursuit of economic activities, ${ }^{28}$ in accordance with the principles of equivalence and effectiveness, ${ }^{29}$ the transferring company can rely on the analogous application of the rules on

22 Judgment of 12 September 2006, Cadbury Schweppes plc, Case C-196/04, ECLI:EU:C:2006:544, especially para. 51, 75

23 SEVIC, op. cit. in fn. 18.

24 Judgement of 16 December 2008, Cartesio Oktató és Szolgáltató bt, C-210/06, ECLI:EU:C:2008:723.

25 Cartesio, op. cit. in fn. 24, para. 110.

26 Cartesio, op. cit. in fn. 24, para. 111-112.

27 Judgement of 12 July 2012, VALE Építési kft, C-378/10, ECLI:EU:C:2012:440.

28 Vale, op. cit. in fn. 27 , para. 34.

29 Vale, op. cit. in fn. 27 , para. 48 
domestic conversions and, for that purpose, use the documents obtained by the authorities of the departure Member State ${ }^{30}$.

In the most recent case, the Court decided on the transfer of a registered seat of a Polish company, called Polbud, to Luxembourg. ${ }^{31}$ Those facts are similar to Vale case, however, with two notable differences. First, it was not the destination, but the departure Member State, Poland, which restricted the transfer by requiring mandatory liquidation of Polbud. Second, Polbud did not intend to transfer its head office or to conduct any economic activity in Luxembourg. ${ }^{32}$ Contrary to the opinion of the Advocate General, Kokott, ${ }^{33}$ The Court concluded that such transfer was covered by the freedom of establishment. ${ }^{34}$ In addition, the Court found that Poland was not authorized to restrict that freedom by requiring liquidation of the company, since mandatory liquidation goes beyond what is necessary to protect the minority shareholders creditors and employees. ${ }^{35}$

Polbud decision, especially the conclusion that the freedom of establishment does not depend on the existence of any actual economic activity was both lauded ${ }^{36}$ and criticized ${ }^{37}$. The aim of this paper is to examine both most im-

$30 \quad$ Vale, op. cit. in fn. 27, para. 60 .

31 Judgement of 25 October 2017, Polbud - Wykonawstwo sp. z o.o., C-106/16, ECLI:EU:C:2017:351.

32 Polbud, op. cit. in fn. 31, para. 8, 26.

33 Opinion of the Advocate General Kokott, 4 May 2017, C-106/16, ECLI:EU:C:2017:351.

34 Polbud, op. cit. in fn. 31, para. 43, 44.

35 Polbud, op. cit. in fn. 31, para. 58, 59.

36 Paefgen, W. G., „Polbud“: Niederlassungsfreiheit als Sitzspaltungsfreiheit, Teil I, WM 2018, p. 981-993; also Paefgen, W. G., „Polbud“: Niederlassungsfreiheit als Sitzspaltungsfreiheit, Teil II, WM 2018, p.1029-1041; Feldhaus, H., Das Erfordernis wirtschaftlicher Inlandstätigkeit beim grenzüberschreitenden (Herein-)Formwechsel nach „Polbud“, BB 2017, p. 28192825, especially p. 2823; Kovács, K., Der grenzüberschreitende (Herein-)Formwechsel in der Praxis nach dem Polbud-Urteil des EuGH, ZIP 2018, p 253-261, especially p. 255-256.

37 Kindler, P., Unternehmensmobilität nach "Polbud": Der grenzüberschreitende Formwechsel in Gestaltungspraxis und Rechtspolitik, NZG 2018, p. 1-7.; Mörsdorf, O., Nun also doch! - Die überraschende Umdeutung der Niederlassungsfreiheit zur Rechtswahlfreiheit durch den EuGH im Urteil Polbud, ZIP 2017, p. 2381-2389; Hushahn, J., Der isolierte grenzüberschreitende Formwechsel - Zugleich Anmerkung zum Urteil des EuGH v. 25.20.2017 in der Rechtssache Polbud, RNotZ 2018, p. 23-25; Kieninger, E.-M., Niederlassungsfreiheit als Freiheit der nachträglichen Rechtswahl, Die Polbud-Entscheidung des EuGH, NJW 2017, p. 36243627; Stelmaszczyk, P., Grenzüberschreitender Formwechsel durch isolierte Verlegung des Satzungssitzes, EuGH präzisiert den Anwendungsbereich der Niederlassungsfreiheit, EuZW 2017, p. 890-894. See also Horak, H.; Dumenčić, K., Cross-Border Transfer of the Company Seat: One Step Forward, Few Step Backward, US-China Law Review, Vol. 14, p. 722, which, although before Polbud decision was rendered, agree with the Opinion of Advocate General as to the requirement of the actual economic activity. 
portant findings of the Court. First, it will be discussed whether a transferring company needs to conduct an actual economic activity in the destination Member State in order to be able to enjoy the freedom of establishment (2.). Second, it will be evaluated whether a mandatory liquidation goes beyond what is necessary to achieve legitimate objectives (3.).

\section{DOES THE FREEDOM OF ESTABLISHMENT ALLOW A COMPANY TO TRANSFER ITS REGISTERED SEAT TO A MEMBER STATE IN WHICH IT DOES NOT CONDUCT ANY ECONOMIC ACTIVITY?}

In allowing Polbud to transfer its registered seat to Luxembourg, the Court relied on the Art 49 (2) TFEU which states that the freedom of establishment includes the right to take up and pursue activities as self-employed persons and to set up and manage undertakings, in particular companies or firms, under the conditions laid down by the law of the country where such establishment is effected for its own nationals. ${ }^{38}$

The Court also relied on its previous decisions, especially in Centros and Cartesio. In Centros it was held that a company with its seat registered in accordance with the laws of one Member State enjoys the freedom to transfer all of its activities to another Member State. Conversely, a company performing all of its activities in one Member State should be allowed to transfer its registered seat to another Member State. ${ }^{39}$ In Cartesio it was held that the power of a Member State to impose requirements on companies incorporated within its legal system does not authorize that Member State to restrict the conversion of those companies to company forms of other Member States. ${ }^{40}$ Consequently, a departure Member State should not be allowed to prevent the transfer of a registered seat to another Member State by demanding mandatory liquidation.

A number of scholars, however, consider that Polbud decision unduly widens the scope of the freedom of establishment from Art. 49 TFEU and that it misinterprets the previous case law. ${ }^{41}$ After all, the Advocate General herself concluded that the transfer of Polbud's registered seat is not covered by the freedom of establishment. ${ }^{42}$ Their main objection is that, as recognized in certain

\footnotetext{
Polbud, op. cit. in fn. 31, para. 33.

39 Polbud, op. cit. in fn. 31, para. 38.

40 Polbud, op. cit. in fn. 31, para. 43.

${ }_{41}$ Especially Kindler, op. cit. in fn. 37, p. 3; Mörsdorf, op. cit. in fn. 37, p. 2382-2385; Stelmaszczyk, op. cit. in fn. 37, p. 893.

42 Opinion of the Advocate General Kokott, op. cit. in fn. 33, para. 33-34.
} 
previous cases, the purpose of the freedom of establishment is to protect an actual, genuine economic activity in a different Member State. ${ }^{43}$ Consequently, the freedom of establishment does not imply a freedom to establish letterbox companies with no connection whatsoever with the destination Member State.

Opponents of Polbud decision believe that even Centros and Cartesio cases do not warrant a different interpretation. In Centros, the Court did not decide on the freedom of Danish citizens to register a company in the UK, but on the freedom of such, already established company to transfer its whole business to Denmark. In other words, the Court merely found that an already established company enjoys the freedom to conduct its actual economic activity in another Member State. ${ }^{44}$ In Cartesio, the famous obiter dictum did not specify whether the right of a company to convert itself into a company form of a different Member State exists without the transfer of any economic activity. It is, however, possible that the Court omitted to clarify that issue only because the company in question wanted to transfer its real seat to Italy. ${ }^{45}$

If Polbud represents a rupture in the existing practice, the Court was at least supposed to provide an elaborate explanation. Instead, the Court failed to even mention the role of an actual economic activity for the definition of the freedom of establishment. ${ }^{46}$ Consequently, the opponents of Polbud decision conclude that the Court's motivation was primarily political - to allow UK companies to circumvent the consequences of Brexit by an easy transfer of their registered seat to another Member State. ${ }^{47}$ The Court, however, neglected the side effects of a precedent that gives a green light to the establishment of letterbox companies - race to the bottom between Member States as to the protection of creditors, minority shareholders and employees, and enabling of tax evasion as demonstrated by recent scandals of Panama Papers and Paradise Papers. ${ }^{48}$

Most of the criticism of Polbud decision, however, does not stand up to scrutiny. Erroneous is already the initial assumption that the transfer of Polbud's

43 Mörsdorf, op. cit. in fn. 37, p. 2383-2384; Hushahn, op. cit. in fn. 37, p. 23; Kindler, op. cit. in fn. 37, p. 3.; Stelmaszczyk, op. cit. in fn. 37, p. 893. See Judgment of the Court of 25 July 1991, The Queen v Secretary of State for Transport, ex parte Factortame Ltd and others, C-221/89, ECLI:EU:C:1991:320, para. 20; Cadbury Schweppes, op. cit. in fn. 22, para. 54; Vale, op. cit. in fn. 27, para. 34, also Forsthoff, op. cit. in fn. 2, para. 16.

44 Mörsdorf, op. cit. in fn. 37, p. 2383-2384; Kindler, op. cit. in fn. 37, p. 3.

45 Cartesio, op. cit. in fn. 24, para., 23, 24, 100-102.

46 About the lack of explanation, Mörsdorf, op. cit. in fn. 37, p. 2382, 2384.

47 Mörsdorf, op. cit. in fn. 37, p. 2388; also Feldhaus, op. cit. in fn. 36, p. 2819 (although he welcomes such motivation).

48 Kindler, op. cit. in fn. 37, p. 1. 
registered seat did not represent an exercise of the freedom to actually perform economic activities (2.1.). Irrespective of that fact, a closer analysis shows that the freedom of establishment is not limited to the pursuit of an actual economic activity in another Member State. Although that is, indeed, its primary purpose, the freedom of establishment also encompasses the freedom to set up companies (and other legal forms) in another Member State under the same conditions as the nationals and companies of that Member State (2.2.). Thus defined, the freedom of establishment will be described both from the perspective of the departure Member State (2.3.) and the destination Member State (2.4.).

\subsection{A COMPANY CAN EXERCISE ITS FREEDOM TO PERFORM ECONOMIC ACTIVITY IN A MEMBER STATE DIFFERENT FROM THE MEMBER STATE OF INCORPORATION EVEN BY A SOLE TRANSFER OF ITS REGISTERED SEAT}

As already explained, the main criticism of Polbud decision was that it expanded the freedom of establishment to encompass the transfer of registered seat without the accompanying transfer of any actual economic activity. ${ }^{49} \mathrm{Such}$ opinion is based on the fact that Polbud transferred its registered seat to Luxembourg while leaving its management and business activities in Poland.

However, that represents a very reductive interpretation of the freedom of establishment. According to Art. 49 (2) TFEU the freedom of establishment includes a "right to take up and pursue activities as self employed persons and to set up and manage undertakings" in another Member State. In other words, the freedom of establishment encompasses not only the right to initiate economic activity but also the right to pursue or perform economic activity. Even further, it can be safely concluded that the right to initiate an economic activity exists only in order for that activity to be performed. In the context of the freedom of establishment of companies (Art. 54 TFEU), the companies have a fundamental right to perform economic activity in another Member State, and different ways to initiate that activity, e.g. by establishing a branch or a subsidiary, or by transferring its seat, are only means of exercising that right.

Having that in mind, Polbud's freedom of establishment did not consist in transferring of its registered seat to Luxembourg but in performing an actual economic activity in a Member State (Poland) different from the Member State of its registration (Luxembourg). The transfer of a registered seat to Lux-

49 Kindler, op. cit. in fn. 37, p. 2; Mörsdorf, op. cit. in fn. 37, p. 2381; Stelmaszczyk, op. cit. in fn. 37, p. 892; Hushahn, op. cit. in fn. 37, p. 24. 
embourg was only a way to exercise such fundamental freedom. Consequently, Poland was not allowed to restrict the performance of economic activity in its territory.

From the perspective of the freedom of establishment the situation in Polbud was not only similar, but identical to the situation in Centros. In both decisions the transferring company exercised its right to perform its activities in a Member State different from the Member State of incorporation. The only difference was reversal of the method through which such right was exercised - in Centros the company transferred its real seat from UK to Denmark, while in Polbud the company transferred its registered seat from Poland to Luxembourg. Consequently, it was only consistent of the Court to prevent the restrictions by the Member State in which transferring company intended to perform its actual economic activity (Denmark, Poland). Furthermore, both decisions confirm the Daily Mail doctrine which allows the Member State of incorporation to impose conditions for company incorporation and functioning. In both cases, the prerequisite for the freedom of establishment was that the state of registration (UK, Luxembourg) did not require a real seat in its territory. ${ }^{50}$

Opponents of the Polbud decision emphasize that the position of creditors, minority shareholders and employees (stakeholders) in Polbud is fundamentally different from the Centros case. In Centros Danish stakeholders would have been aware that they enter into a legal relationship with a newly arrived UK company. ${ }^{51}$ In Polbud, on the other hand, Polish stakeholders could lose the already acquired level of protection after the company becomes subject to the law of Luxembourg. ${ }^{52}$ Although such observation is entirely correct, a decision whether a company enjoys freedom of establishment cannot be influenced by the position of creditors, minority shareholders and employees. In accordance with the consistent practice of the Court, protection of minority shareholders, creditors, employees serves as a justification for the restrictions of the freedom of establishment. ${ }^{53}$ The very fact that the freedom of establishment is being restricted confirms that it existed in the first place.

In addition, minority shareholders, creditors and employees would be equally endangered if Polbud transferred a part or its whole economic activity to Luxembourg. Consequently, their position cannot be used to criticize the transfer of the registered seat without an accompanying economic activity.

\footnotetext{
50 Centros, op. cit. in fn. 11, para. 27; Polbud, op. cit. in fn. 31, para. 43.

51 Kindler, op. cit. in fn. 37, p. 3-4, see also Centros, op. cit. in fn. 11, para. 36.

52 Kindler, op. cit. in fn. 37 , p. 4.

53 Überseering, op. cit. in fn. 13, para. 92; SEVIC op. cit. in fn. 18, para. 28; Vale, op. cit. in fn. 27, para. 39; Polbud, op. cit. in fn. 31, para. 54.
} 


\subsection{THE RELATIONSHIP BETWEEN THE FREEDOM OF ESTABLISHMENT AND THE ACTUAL ECONOMIC ACTIVITY}

The previous chapter (2.1.) as well as the criticism of Polbud decision is based on the assumption that the freedom of establishment is limited to the freedom to pursue an actual economic activity. That statement, however, has to be closely examined. It is remarkable that TFEU does not give a comprehensive definition of the establishment. ${ }^{54}$ Art. 49 (1) TFEU merely prohibits the restrictions on the freedom of establishment of nationals of a Member State in the territory of another Member State, including the restrictions on the setting-up of agencies, branches or subsidiaries by nationals of any Member State established in the territory of any Member State. Art. 49 (2) TFEU, only as an example, states that the freedom of establishment "shall include the right to take up and pursue activities as self-employed persons and to set up and manage undertakings, in particular companies or firms".

The precise notion of establishment has, therefore, been left to the case law and jurisprudence. In Factortame II case the Court has given a definition of the establishment as an "actual pursuit of an economic activity through a fixed establishment in another Member State for an indefinite period". ${ }^{55}$ The need for an actual pursuit of economic activity was upheld in Cadbury Schweppes case,${ }^{56}$ and in one of the most recent cases on cross-border transfer of the seat, Vale ${ }^{57}$. Namely, the Court allowed the transfer of the registered seat from Italy to Hungary because there was nothing to suggest that the activities of the transferring company will be restricted to Italy. ${ }^{58}$ The requirement of an actual pursuit of an economic activity has been widely accepted in legal scholarship. ${ }^{59}$ Even further, a number of scholars consider that an actual economic activity within the EU, or even the departure Member State, is a prerequisite for the freedom of establishment. ${ }^{60}$ In other words,

\footnotetext{
54 Forsthoff, op. cit. in fn. 2, AEUV Art. 49, para. 16.

55 Factortame II; op. cit. in fn. 43, para. 20.

56 Cadbury Schweppes, op. cit. in fn. 22, para. 54.

57 Vale, op. cit. in fn. 27, para. 34

58 Vale, op. cit. in fn. 27, para. 35.

59 Barnard, op. cit. in fn. 2, p. 383; Craig; de Burca, op. cit. in fn. 2, p. 794-795; Forsthoff, op. cit. in fn. 2, AEUV Art. 49, para. 16.; Müller-Graf, op. cit. in fn. 2, AEUV Art. 49, para. 12, Korte, op. cit. in fn. 2, AEUV Art. 49, para. 25-28, 32; Tiedje, op. cit. in fn. 2, AEUV Art. 49, para. 12

60 Tiedje, op. cit. in fn. 2, AEUV Art. 54, para. 29.; Kindler, P., Der reale Niederlassungsbegriff nach dem VALE-Urteil des EuGH, EuZW 2012, p. 892: Böttcher, L.; Kraft, J., Grenzüberschreitender Formwechsel und tatsächliche Sitzverlegung - Die Entscheidung VALE des EuGH, NJW 2012, p. 2701; Roth, G., Das Ende der Briefkastengründung? - Vale contra Cen-
} 
they treat the actual economic activity as an unwritten requirement from Art. 54 TFEU. ${ }^{61}$

The purpose of the freedom of establishment is indeed to enable an actual pursuit of a real economic activity. This is evident from the fact that it is located within Title IV of TFEU on free movement of persons, services and capital. After all the internal market (Art. 26 TFEU) presupposes an actual economic activity. ${ }^{62}$ However, in order to achieve uniformity, publicity, and legal certainty, Member States usually provide that economic activities have to be performed through a certain, usually registered, legal form. ${ }^{63}$ This can already be discerned from Art. 49 TFEU which mentions agencies, branches, subsidiaries, undertakings, companies and firms. The precise definition of those notions is left to individual Member States. This is most obvious for companies and firms which exist only in accordance with the laws of a Member State (Art. 54 (1) TFEU).

Naturally, national definitions of available legal forms should not hinder the freedom of establishment. This does not mean that a Member State cannot provide even for substantial requirements for a specific legal form. Member States are merely compelled to leave at least one legal form through which EU nationals and companies can perform economic activities without any substantial burden. Thus, a Member State may place significant requirements on the incorporation of its companies, ${ }^{64}$ as long as it allows for another way of performing economic activities, e.g. by registration of a branch.

On the other hand, after a Member State institutes certain legal forms suitable for performing economic activities, in order to avoid discrimination (Art. 18 TFEU) ${ }^{65}$ they have to be available under the same conditions to all EU nationals and companies. ${ }^{66}$ It is, however, possible that a Member State does not require that those forms are indeed used for performing of actual economic activities. Even in that case, in order to avoid discrimination, those forms have

tros, ZIP 2012, p. 1745; Leible, S., EuGH: Eintragung der Zweigniederlassung einer in einem anderen Mitgliedstaat ansässigen und rechtmäßig gegründeten Gesellschaft, die dort keine Geschäftstätigkeit entfaltet; NZG 1999, p. 301; Mörsdorf, op. cit. in fn. 37, p. 2384.

${ }_{61}$ Tiedje, op. cit. in fn. 2, AEUV Art. 54, para. 29., see also Korte, op. cit. in fn. 2, AEUV Art. 54, para. 18-20.

62 Mörsdorf, op. cit. in fn. 37, p. 2384.

63 Daily Mail, op. cit. in fn. 3, para. 17; Centros, op. cit. in fn. 11, para. 20.

64 Daily Mail, op. cit. in fn. 3, especially para. 20, 23.

65 That the freedom of establishment retains a close connection to the general prohibition of discrimination from Art. 18 TFEU see Müller-Graf, op. cit. in fn. 2, Art. 49 AEUV, para. 111.

66 Tiedje, op. cit. in fn. 2, AEUV Art. 49, para. 54. 
to stay available for all EU nationals and companies. This is confirmed by Art. 49 (2) TFEU which states that the "freedom of establishment shall include the right ... to set up and manage undertakings, in particular companies or firms ... under the conditions laid down for its own nationals by the law of the country where such establishment is effected...”. Art 49 (2) TFEU, thus, suggests that the mere establishing and managing of companies falls under the definition of establishment. This interpretation is supported by the existing case law. In Daily Mail the Court concluded that "a company may also exercise its right of establishment by taking part in the incorporation of a company in another Member State". ${ }^{67}$ In Centros the Court held that "the right to form a company in accordance with the law of a Member State and to set up branches in other Member States in inherent in the exercise, in a single market, of the freedom of establishment" ${ }^{68}$

Opponents of such interpretation believe that, especially in regard to establishing of companies, an economic activity, a "real connection", is necessary to protect the departure Member State from letterbox companies, forum shopping, race to the bottom, tax fraud, abuse, and other similar evils. ${ }^{69}$ However, the problem is how to determine the economic activity in the moment of applying for an establishment. EU nationals and companies obviously do not have to be economically active in a Member State which they are just trying to enter. Consequently, both departure and destination Member State often have to satisfy themselves with an intention to initiate an economic activity. ${ }^{70} \mathrm{Such}$ intention is notoriously difficult to prove, especially since the legal subject seeking establishment cannot be forced to make any investment in advance. This leads to a vicious circle - a Member State is not obliged to allow a legal subject to establish itself before it proves the seriousness of its intent, and a legal subject cannot be obliged to demonstrate its seriousness before it is granted an establishment. Moreover, even if a legal subject succeeds in proving that it intends to perform an economic activity, nothing can prevent it from subsequently changing its mind and ceasing with such activity.

Even if those problems are somehow solved, and a Member State is able to verify continuous economic activity of formally established legal subjects, this would not necessarily prevent abuse and "shopping" of the most favorable legal system. Namely, the performance of an economic activity does not ensure that a company is substantially connected to a legal system. Large enterprises

\footnotetext{
Daily Mail, op. cit. in fn. 3, para. 17

Centros, op. cit. in fn. 11, para. 27.

69 Kindler, op. cit. in fn. 37, p. 1 and pass.

70 Opinion of the Advocate General Kokott, op. cit. in fn. 33, para. 36.
} 
could easily afford to perform a negligible amount of economic activity in a Member State which they deem as a legally desirable registered seat. This goes to the heart of the problem. Against the backdrop of a globalized economy and technological inventions a company can easily have a "real connection" with so many legal systems that the very reason for requiring a real connection is lost. Naturally, this does not mean that Member States should not fight tax fraud and abuse, but this should rather be done by converging legal standards through a political process on the EU level than by denying access to legal forms under the pretext that there is no economic activity.

To sum up, the freedom of establishment has two aspects. First, the freedom to actually perform economic activities, which compels the destination Member State to offer EU nationals and companies at least one legal form without any substantial requirements for performing of those activities (freedom of economic activity). Second, the freedom to use all legal forms of the destination Member State suitable for performing economic activities, under the conditions for its own nationals and companies, irrespective of the fact whether the economic activities are actually being performed (freedom of legal form). This second aspect corresponds to the general prohibition of discrimination from Art. 18 TFEU.

Such distinction was recognized in SEVIC case. The Court acknowledged that the right of establishment generally "covers all measures which permit or even facilitate access to another Member State and the pursuit on an economic activity in that State". ${ }^{71}$ However, in regard to companies, the freedom of establishment "includes in particular the formation and management of those companies under the conditions defined by the legislation of the State of establishment for its own companies". ${ }^{72}$ Thus, without any reference to an actual economic activity the Court concluded that cross-border merger operations "constitute particular methods of exercise of the freedom of establishment" ${ }^{3}$

Although independent, the freedom of legal form retains a certain connection to its original purpose - to allow the performance of an actual economic activity. Consequently, the restrictions of the freedom of legal form can be more easily justified if it is not exercised to actually perform an economic activity. This proves to be the exact context in which the above-mentioned decisions Cadbury Schweppes and Vale require an actual economic activity. In Cadbury Schweppes the Court did not deny that establishing of a company in Ireland

$71 \quad$ SEVIC, op. cit. in fn. 18, para. 18.

72 SEVIC, op. cit. in fn. 18, para. 17.

73 SEVIC, op. cit. in fn. 18, para. 19. 
was covered by the freedom of establishment of the UK company. ${ }^{74}$ Only in a second step, when deliberating whether a restriction of such freedom was justified, the court stated that "the objective" pursued by the freedom of establishment is to participate in the economic life of another Member State. ${ }^{75}$ Even if that objective is not met, the restriction of the freedom of establishment is not automatically justified, but only if there is an additional, "subjective element consisting in the intention to obtain a tax advantage". ${ }^{76}$ In a relatively similar, although less clear fashion, the Court in Vale mentioned an actual pursuit of an economic activity only in the context of restrictions on the freedom of establishment and their justification, after it has already established that the national legislation which enables a conversion of national, but not foreign companies, falls under the scope of Articles 49 and 54 TFEU. ${ }^{77}$

It can be concluded that the lack of an actual economic activity can play a (not entirely clear) role in justifying the restrictions of freedom of legal form. However, the lack of an actual economic activity cannot automatically exclude the freedom to use legal forms under the conditions available for domestic legal subjects.

\subsection{THE FREEDOM OF ESTABLISHMENT FROM THE PERSPECTIVE OF THE DEPARTURE MEMBER STATE}

Art. 49 TFEU expressly prohibits only the restrictions of the freedom of establishment set by the destination Member State. Narrowly interpreted, this could mean that the departure Member State is free to restrict the freedom of establishment as much as it wants. Since this would practically render the freedom of establishment meaningless, it is universally accepted that the restrictions set by the departure Member State are equally prohibited..$^{78}$

The departure Member State is, thus, in principle, prohibited to restrict either the freedom of economic activity or the freedom of legal form in the destination Member State. However, if those freedoms are exercised by a company, the departure Member State has the power to restrict them indirectly, by setting the requirements for the incorporation of a company. As already mentioned, a company can exercise its freedom of establishment only if it exists by virtue

\footnotetext{
74 Cadbury Schweppes, op. cit. in fn. 22, para. 31, 37.

75 Cadbury Schweppes, op. cit. in fn. 22, para. 53

76 Cadbury Schweppes, op. cit. in fn. 22, para. 64

77 Vale, op. cit. in fn. 27, para. 34.

78 Craig; de Burca, op. cit. in fn. 2, p. 807.
} 
of a national legislation (Art. 54 TFEU). ${ }^{79}$ The Member State of incorporation can, thus, require, that its company has a certain type of "real" connection to its territory, e.g. through its central management or its economic activity. The Member State of incorporation can also set other requirements, usually a minimum share capital. The power of the Member State is, however, not without its limits. The incorporation of a company is not only a prerequisite for the freedom of its establishment, but also an expression of the freedom of establishment of its founders (Art. 49 (2) TFEU). From that angle, the Member State of incorporation is a destination Member State, whose limitations will be explained in the corresponding chapter. ${ }^{80}$

The relationship between the national company law and the EU freedom of establishment gets more complicated after the company is incorporated. On one hand, the existence of such company and its affiliation remain dependent on the Member State of incorporation (the departure Member State) ${ }^{81}$ On the other hand, such company acquires its own freedom of establishment that the Member State of incorporation should not restrict (Art. 54, 49 TFEU). Since the existence of a company remains a prerequisite for its freedom of establishment, certain priority has to be given to the national law. The Member State can still impose requirements on its company and even cease to recognize or wind-up a company that fails to meet them. ${ }^{82}$ This was the situation in Daily Mail and Cartesio case, in which it was held that the departure Member State is allowed to require the existence of a certain real connection with its territory. ${ }^{83}$

The Member State of incorporation, however, has to take into account the company's freedom of establishment. Therefore, it has to refrain from imposing requirements whose primary goal is to prevent such freedom. The Member State of incorporation could not, in a general way, prohibit its companies from performing economic activities in another Member State. It is important to note the fine demarcation between the power of the Member States and the EU freedom of establishment. The Member State of incorporation could require that a company has its central management or that it performs economic activities in its territory, but it could not demand that all of company's economic activities are performed there.

\footnotetext{
79 Daily Mail, op. cit. in fn. 3, para. 19.

80 Section 2.2.2.

81 Daily Mail, op. cit. in fn. 3, para. 19, 20, which state that the national law determines company "incorporation and functioning" and "whether a company incorporated under the legislation of a Member State may subsequently modify the connecting factor". Also Cartesio, op. cit. in fn. 24, para. 104, 105.

82 Daily Mail, op. cit. in fn. 3, para. 18, 24; Cartesio, op. cit. in fn. 24, para. 110.

83 Daily Mail, op. cit. in fn. 3, para. 24; Cartesio, op. cit. in fn. 24, para. 110
} 
Similarly, the Member State of incorporation could not prohibit its companies from setting up legal forms intended for performing of an economic activity in another Member State, irrespective from the fact whether the economic activity is actually performed. Setting up legal forms without any economic activity could be prevented only by the destination Member State (see 2.4.).

Reached conclusions are equally applicable on the situation in which a company wishes to transfer its registered seat to another Member State (with or without the transfer of the real seat). By an analogy with EU nationals (Art. 49 TFEU), a company should be able to change its place of primary establishment, i.e. to transfer its registered seat. ${ }^{84}$ Since companies are creatures of national law, they can transfer their registered seat only by converting their whole legal identity to a legal form of the destination Member State. By such conversion a company terminates its affiliation with the departure Member State. Considering that the departure Member State determines the functioning of its companies, it is generally authorized to set requirements for company termination. However, if a company does not cease to exist, but merely continues its existence in another Member State, the departure Member State has to respect such freedom. This was the situation in Polbud (and obiter dictum in Cartesio), where the Court found that the transferring company enjoys a freedom of establishment in respect to the departure Member State. ${ }^{85}$ The departure Member State could only impose the restrictions which are justified on the basis of overriding public interests, appropriate for ensuring of the objectives pursued and do not go beyond what is necessary (see 3.). ${ }^{86}$

\subsection{THE FREEDOM OF ESTABLISHMENT FROM THE PERSPECTIVE OF THE DESTINATION MEMBER STATE}

The destination Member State is not allowed to prevent nationals and companies from other Member States from actually pursuing an economic activity within its boundaries. Literally, this means that the destination Member State has to let those nationals and companies to perform their activities directly, without any formal requirements. However, the destination Member State

${ }^{84}$ If the freedom of establishment encompasses the freedom of legal form, the place of registration is the place of primary establishment.

85 Cartesio, op. cit. in fn. 24, para. 111-112; Polbud, op. cit. in fn. 31, para. 43.

86 See Paefgen, Teil I, op. cit. in fn. 36, p. 986, who considers that this overrules Daily Mail principle of the autonomy of the Member State of incorporation. However, even Daily Mail decision hints that the Member State of incorporation would not be able to impose restrictions on the companies who do not retain their status as companies incorporated under the legislation of that Member State. (Daily Mail, op. cit. in fn. 3, para. 24). 
has a legitimate public interest to have an overview of legal subjects which perform economic activities in its territory. Therefore, the destination Member State is allowed to require that the economic activity is exercised through certain legal forms, usually subject to some kind of registration. TFEU itself mentions branches, agencies, subsidiaries, companies and firms (Art. 49). An already existing company, which merely seeks a secondary establishment, performs its economic activity through branches, agencies or subsidiaries (Art. 49 (1) TFEU).

Since all mentioned legal forms are creatures of national law, the destination Member State is, in principle, authorized to set the requirements for their formation. Those, requirements, however, should not restrict the freedom to perform an actual economic activity. This leads to a conclusion that the destination Member State has to leave at least one legal form which can be used by the nationals and companies from other Member States without any significant obstacles. This was the basic problem in Centros and Inspire Art cases. In both decisions, the refusal of the registration authority to register a branch and the requirement of a minimum share capital for registering a branch would not represent a restriction of the freedom of establishment if the company in question could conduct economic activity in the destination Member State (Denmark, Netherlands) in some other way. However, since Denmark and Netherlands required that foreign companies perform their economic activity through a branch, ${ }^{87}$ they were prohibited to place any significant restrictions on their formation.

The destination Member State is equally not allowed to prevent nationals and companies from other Member States from using all of its legal forms suitable for performing of economic activities under the conditions set for its own national and companies. ${ }^{88}$ This follows already from the general prohibition of discrimination (At. 18 TFEU) and is explicitly confirmed by Art. 49 (2) TFEU. In other words, if an actual pursuit of an economic activity or a minimum share capital is not required from legal subjects of the destination Member State, it cannot be required from foreign legal subjects. Vice versa, if a destination Member State requires actual economic activity or a minimum share capital for its own nationals and companies, it can equally impose those requirements on foreign national and companies.

This was confirmed by SEVIC case, in which the Court found that a general refusal that companies from another Member State are merged with domestic

\footnotetext{
Centros, op. cit. in fn. 11, para. 5.

88 Tiedje, op. cit. in fn. 2, AEUV Art. 49, para. 54.
} 
company forms is contrary to the freedom of establishment. ${ }^{89}$ This was basically also the situation in Vale case, irrespective of the fact that the Court defined the freedom of establishment through the actual pursuit of an economic activity. The Court found that the destination Member State was allowed to set the requirements for domestic conversion, however, once those requirements are set, they have to be available to nationals and companies from other Member States. ${ }^{90}$ Particularly, the rules on cross-border conversions cannot be less favorable than the rules on domestic conversions (principle of equivalence) ${ }^{91}$ and the destination Member State has to accept documents obtained from the authorities of the departure Member State (principle of effectiveness). ${ }^{92}$

\section{DOES A MANDATORY LIQUIDATION GO BEYOND WHAT IS NECESSARY TO PROTECT THE LEGITIMATE INTERESTS OF MINORITY SHAREHOLDERS, CREDITORS OR EMPLOYEES OF THE COMPANY?}

After it is determined that transferring company enjoys a freedom of establishment and that such freedom was restricted, it remains to be determined whether such restriction may be justified in order to prevent fraud or abuse or because of some other overriding reason of public interest, most commonly the protection of minority shareholders, creditors, employees (workers) or tax law objectives. ${ }^{93}$ The restriction may be justified only if it is appropriate for attaining of its objective and if it does not go beyond what is necessary to attain it. ${ }^{94}$

In Polbud, the Court allowed the possibility that Polish rules on mandatory liquidation of the transferring company have a legitimate objective of protecting minority shareholders, creditors and employees of the company. ${ }^{95}$ However, the Court held that such measure goes beyond what is necessary to attain those objectives since the liquidation of the company is required generally, without the consideration of the actual risk of detriment to the interests of creditors and

\footnotetext{
89 SEVIC, op. cit. in fn. 18 , para. 30.

90 Vale, op. cit. in fn. 27, para. 27-29, 32, 36.

91 Vale, op. cit. in fn. 27, para. 54.

92 Vale, op. cit. in fn. 27, para.58, 60.

93 Centros op. cit. in fn. 11, para. 25, 34; Überseering, op. cit. in fn. 13, para. 92; Inspire Art, op. cit. in fn. 14, para. 105, 133; SEVIC, op. cit. in fn. 18, para. 28; Vale, op. cit. in fn. 27, para. 39; Polbud, op. cit. in fn. 31, para. 52.

94 Centros op. cit. in fn. 11, para. 34; SEVIC, op. cit. in fn. 18, para. 29; Vale, op. cit. in fn. 27, para. 39; Polbud, op. cit. in fn. 31, para. 52.

95 Implicitly, Polbud, op. cit. in fn. 31, para. $52-57$ also Paefgen, Teil I, op. cit. in fn. 36, p. 987.
} 
employees, and without the possibility of choosing a less restrictive measure. ${ }^{96}$ In particular, the Court believes that the provision of bank guarantees or other equivalent guarantees could offer adequate amount of protection to the endangered interests. ${ }^{97}$ Such opinion represents a continuation of the reasoning from obiter dictum in Cartesio, according to which the departure Member State is not justified in restricting the freedom of establishment by requiring the winding-up or liquidation of the company. ${ }^{98}$

Although such conclusion was less criticized that the finding that Polbud enjoys the freedom of establishment, it is not without its controversies. As already mentioned, ${ }^{99}$ the existing creditors, minority shareholders and employees of a company which converts to a legal form of another Member State may find themselves in a dire position if the destination Member State provides for a lower level of their protection. This is fundamentally different from the Centros situation in which a company merely transfers its real seat while retaining its legal identity. Such considerations, which were deemed insufficient to generally exclude the freedom of establishment, are all the more important when assessing the justifications for restrictions of the freedom of establishment.

The brief explanation given by the Court can be described as superficial if not irresponsible. The fact that the Polish legislation prescribes mandatory liquidation generally does not mean that it does not take into account the actual risk of detriment to the interests of stakeholders. On the contrary, it seems that the very purpose of liquidation under Polish law is to determine who are the creditors of the company, to satisfy their claims and afterwards, to distribute the company assets among the shareholders. ${ }^{100}$

Similarly, it is not self-evident that the provision of bank guarantees or other equivalent guarantees would be less burdensome for the company than the liquidation procedure. ${ }^{101}$ It is not likely that the bank will issue a guarantee unless it receives collateral of a corresponding value, and if the company is able to

\footnotetext{
96 Polbud, op. cit. in fn. 31, para. 58-59.

97 Polbud, op. cit. in fn. 31, para. 58.

98 Cartesio, op. cit. in fn. 24, para. 112.

99 Section 2.1.

100 Polbud, op. cit. in fn. 31, para. 50, which states that the liquidation under Polish law includes the conclusion of current business, recovery of debts, fulfilment of obligations and sale of company assets, satisfaction or securing of creditors, submission of a financial statement on the conduct of those acts, and indication of the person to whom the books and documents are to be entrusted. As to the distribution of assets among shareholders see para. 5 .

101 It seems that the Court reflected an equally unsubstantiated statement from Centros, op. cit. in fn. 11, para. 37.
} 
provide such collateral, the satisfaction of creditors in the course of liquidation would presumably also not be a problem.

A potential problem with liquidation could be that liquidation usually terminates the company, which could, at least from perspective of the departure Member State, prevent the continuation of company's legal personality in the destination Member State. However, it seems that this is not in case with the Polish law. In fact, the Court itself observed that the transfer of the registered office of a company incorporated under Polish law to another Member State does not entail the loss of legal personality. ${ }^{102}$

Another potential shortcoming of Polish liquidation procedure could be that it extinguishes, if not company itself, all of company's legal relationships. ${ }^{103}$ This could especially be a problem in the case of long-lasting contractual relationships, where both the company and its contractual partners may have a legitimate expectation to continue the relationship in the future. ${ }^{104}$ However, the Court failed to recognize that and to demonstrate that there was a less restrictive measure which would protect the interests of minority shareholders, creditors and employees.

Generally speaking, less restrictive measures for the protection of company stakeholders could be contained within the provisions of the departure Member State on domestic conversions. It can be presumed that those provisions would ensure a smoother transition of company personality and all of its legal relationships to a company form of the destination Member State. This would represent a solution similar to the solution from the Vale case, only from the perspective of the departure Member State. In Vale, the Court found that the destination Member State has to allow that companies from other Member States convert to its own company forms by an analogous application of the rules on domestic conversions. Similarly, the departure Member State would have to allow its companies to convert to a company form of another Member State in accordance with the rules on domestic conversions. In other words, as already announced in Vale, the conversion would be effected by a consecutive application of two national laws on company conversion. ${ }^{105}$

It seems that the Court in Polbud also suggested such solution. It held that the departure Member State is not authorized to prevent a company from cross-border conversion by imposing "conditions that are more restrictive than

\footnotetext{
102 Polbud, op. cit. in fn. 31, para. 47.

103 See fn. 100, especially the reference to the conclusion of current business.

104 See Opinion of the Advocate General Kokott, op. cit. in fn. 33, para. 57, for employment contracts.

105 Vale, op. cit. in fn. 27, para. 37.
} 
those that apply to the conversion of a company within that Member State itself". ${ }^{106}$ From such wording, it can be concluded that the departure Member State would be allowed to impose the national requirements for the conversion of its companies.

In any case, it is impossible to conclude on an abstract level which procedure for protecting company stakeholders is least restrictive. This can be determined only after a careful assessment of specific requirements for the company liquidation or its conversion under a national law. In particular case it is possible that both liquidation and conversion procedures go beyond what is necessary to attain legitimate objective. Also, although not very likely, it is theoretically possible that the conversion procedure is more restrictive than the liquidation procedure.

\section{CONCLUSION}

The analysis of Polbud has demonstrated that the most recent decision on the transfer of the company seat represents rather a continuation than a rupture with the previous case law of the Court. Therefore, it may seem surprising that the decision was widely criticized in jurisprudence. Most controversial was the fact that Polbud was granted the freedom of establishment to transfer its registered seat although it did not intend to perform any economic activity in the destination Member State. In that respect, the Advocate General and a number of scholars consider that, first, an actual economic activity is a prerequisite for the notion of establishment and, second, that Polbud could not rely on such freedom since it exclusively transferred its registered seat. However, neither of those conclusions is accurate.

It is true that the purpose of the freedom of establishment is to protect the pursuit of an actual economic activity and, thus, the internal market. In order to have an overview of the economic activity in their territory, Member States, however, usually grant the establishment through certain, usually registered, legal forms, such as branches, agencies and companies. The existence of those forms does not restrict the freedom of establishment as long as there is at least one legal form through which the nationals and companies from other Member States can perform an economic activity without any substantial requirements (freedom of economic activity).

On the other hand, a Member State may choose to set legal forms suitable for performing economic activity even without requiring any actual economic

106 Polbud, op. cit. in fn. 31, para. 43 
activity. Although such forms do not necessarily perform their original function, in order to prevent discrimination (Art. 18, 49 (2) TFEU), a destination Member State has to make them available under the same conditions to all EU nationals and companies (freedom of legal form).

A departure Member State might have an interest to prevent companies from circumventing its national law by transferring their registered company seat to a destination Member State which does not require an actual economic activity. Such interest, however, should not be given priority over the freedom of legal form. First, at the moment of giving permission to establish a legal form in the destination Member State it is very difficult to prove the company's intention to perform an economic activity. Even if that intention is somehow proven, the departure Member State cannot prevent the company from discontinuing such activity as soon as it is formally established. Finally, the underlying reason for insisting on an economic activity is becoming more and more obsolete. Insisting on an actual economic activity is based on the idea of a real existence of a company in a certain territory. However, with the globalization of economy and the technological innovation, instead of having a strong connection with one country, a company may easily have relatively weak connections with many countries. In that context, tying the company identity to some kind of "real seat" is often futile.

Moreover, the decision reached in Polbud would be correct even if an actual economic activity was a necessary prerequisite of the freedom of establishment. The true content of Polbud's freedom of establishment was not the transfer of the registered seat to Luxembourg, but the performance of an economic activity in a Member State (Poland) different from the Member State of registration (Luxembourg). In other words, the freedom of establishment should not be reduced to the freedom to initiate an economic activity or to move it to another Member State. On the contrary, the freedom to initiate or to move an economic activity is just a tool for the cross-border performance of that activity. In other words, from the perspective of the freedom of establishment, the situation in Polbud is identical to the situation in Centros.

Second conclusion of the Court in Polbud - that a mandatory liquidation goes beyond what is necessary to achieve the legitimate interests of protecting minority shareholders, creditors or employees of the company - is less justified. It is superficial to claim that the procedure whose aim is to determine the existence of creditors and their claims does not take into consideration the actual risk of detriment to their interests. This does not mean that the decision reached by the Court is necessarily incorrect. Generally speaking, the provisions of the departure Member State on the conversion of its own companies should be less restrictive than the provisions on company liquidation. However, that had to be determined and explained by the Court in more detail. 


\section{LITERATURE}

1. Barnard, C., The Substantive Law of the EU, The Four Freedoms, Oxford University Press, 2016.

- DOI: https://doi.org/10.1093/he/9780198749950.001.0001

2. Böttcher, L.; Kraft, J., Grenzüberschreitender Formwechsel und tatsächliche Sitzverlegung - Die Entscheidung VALE des EuGH, NJW 2012, p. 2701-2704

3. Craig, P.; de Burca, G., EU Law, Text, Cases and Materials, Oxford University Press, 2015.

- DOI: https://doi.org/10.1093/he/9780198714927.001.0001

4. Feldhaus, H., Das Erfordernis wirtschaftlicher Inlandstätigkeit beim grenzüberschreitenden (Herein-) Formwechsel nach „Polbud“, BB 2017, p. 2819-2825

5. Forsthoff, U. in Grabitz, E.; Hilf, M.; Nettesheim, M. (ed.), Das Recht der Europäischen Union, C. H. Beck; München, 2018., AEUV Art. 49

6. Garcimartin, F., a proposal by the European Group for Private International Law (GEDIP):The Law Applicable to Companies in the European Union, October 2016

7. Gerner-Beuerle, C.; Mucciarelli, F. M.; Schuster, E-P., Study on the Law Applicable to Companies, June 2016

8. Goebel, R. J. et al., Cases and Materials on European Union Law, West Academic Publishing, 2015.

9. Horak, H.; Dumenčić, K., Cross-Border Transfer of the Company Seat: One Step Forward, Few Step Backward, US-China Law Review, Vol. 14, p. 722

10. Hushahn, J., Der isolierte grenzüberschreitende Formwechsel - Zugleich Anmerkung zum Urteil des EuGH v. 25.20.2017 in der Rechtssache Polbud, RNotZ 2018, p. 23-25

11. Kieninger, E.-M., Niederlassungsfreiheit als Freiheit der nachträglichen Rechtswahl, Die Polbud-Entscheidung des EuGH, NJW 2017, p. 3624-3627

12. Kindler, P., Der reale Niederlassungsbegriff nach dem VALE-Urteil des EuGH, EuZW 2012, p. 888-892

13. Kindler, P., Unternehmensmobilität nach „Polbud“: Der grenzüberschreitende Formwechsel in Gestaltungspraxis und Rechtspolitik, NZG 2018, p. 1-7

14. Korte S. in: Calliess, C.; Ruffert, M. (ed.), EUV/AEUV, C. H. Beck, München, 2018., Art. 49 AEUV

15. Kovács, K., Der grenzüberschreitende (Herein-)Formwechsel in der Praxis nach dem Polbud-Urteil des EuGH, ZIP 2018, p 253-261

16. Leible, S., EuGH: Eintragung der Zweigniederlassung einer in einem anderen Mitgliedstaat ansässigen und rechtmäßig gegründeten Gesellschaft, die dort keine Geschäftstätigkeit entfaltet; NZG 1999, p. 298-302 
17. Mathijsen, P. S. R. F., A Guide to European Union Law, Sweet \& Maxwell, 2010.

18. Mörsdorf, O., Nun also doch! - Die überraschende Umdeutung der Niederlassungsfreiheit zur Rechtswahlfreiheit durch den EuGH im Urteil Polbud, ZIP 2017, p. 2381-2389

19. Müller-Graf, P-C. in Streinz, R. (ed.), EUV/AEUV, C. H. Beck, München, 2018., AEUV Art. 49

20. Paefgen, W. G., „Polbud“: Niederlassungsfreiheit als Sitzspaltungsfreiheit, Teil I, WM 2018, p. 981-993

21. Paefgen, W. G., „Polbud“: Niederlassungsfreiheit als Sitzspaltungsfreiheit, Teil II, WM 2018, p.1029-1041

22. Roth, G., Das Ende der Briefkastengründung? - Vale contra Centros, ZIP 2012, p. $1744-1745$

23. Stelmaszczyk, P., Grenzüberschreitender Formwechsel durch isolierte Verlegung des Satzungssitzes, EuGH präzisiert den Anwendungsbereich der Niederlassungsfreiheit, EuZW 2017, p. 890-894

24. Steiner, J.; Woods, L., EU Law, Oxford University Press, 2009.

25. Tiedje, J. in: von der Groeben, H.; Schwartze, J., Hatje, A. (ed.), Europäische Unionsrecht, Nomos, 2015., AEUV Art. 49

\section{CASES}

1. Judgement of 27 September 1988, Daily Mail and General Trust PLC, C-81/87, ECLI:EU:C:1988:456

2. Judgment of the Court of 25 July 1991, The Queen v Secretary of State for Transport, ex parte Factortame Ltd and others, C-221/89, ECLI:EU:C:1991:320

3. Judgement of 9 March 1999, Centros Ltd, C-212/97, ECLI:EU:C:1999:126

4. Judgement of 5 November 2002, Überseering BV v Nordic Construction Company Baumanagement GmbH (NCC), C-208/00, ECLI:EU:C:2002:632

5. Judgement of 30 September 2003, Kamer van Koophandel en Fabrieken voor Amsterdam v Inspire Art Ltd, Case C-167/01, ECLI:EU:C:2003:512

6. Judgement of 13 December 2005, SEVIC Systems AG, C-411/03, ECLI:EU:C:2005:762

7. Judgment of 12 September 2006, Cadbury Schweppes plc, Case C-196/04, ECLI:EU:C:2006:544

8. Judgement of 16 December 2008, Cartesio Oktató és Szolgáltató bt, C-210/06, ECLI:EU:C:2008:723

9. Judgement of 12 July 2012, VALE Építési kft, C-378/10, ECLI:EU:C:2012:440

10. Judgement of 25 October 2017, Polbud - Wykonawstwo sp. z o.o., C-106/16, ECLI:EU:C:2017:351

11. Opinion of the Advocate General Kokott, 4 May 2017, C-106/16, ECLI:EU:C:2017:351 